\title{
SOME OBSERVATIONS ON THE INFLUENCE OF A MAGNESIUM- DEFICIENT DIET ON RATS, WITH SPECIAL REFERENCE TO RENAL CONCENTRATING ABILITY*
}

\author{
By ANDRZEJ MANITIUS $†$ AND FRANKLIN H. EPSTEIN
}

(From the Department of Internal Medicine, Yale School of Medicine, New Haven, Conn.)

(Submitted for publication July 20, 1962 ; accepted October 19, 1962)

Impairment of renal concentrating ability is usually considered a hallmark of potassium depletion, occurring early in its development. The presence of this defect is not thought to be related to the cause of potassium depletion $(1,2)$. Potassium depletion can be induced in rats by a diet deficient in magnesium but containing normal amounts of potassium $(3,4)$. Recently Whang and Welt observed that even an increased supply of potassium in the diet does not prevent magnesium-deficient rats from developing depletion of muscle potassium (5).

It seemed of interest to study the influence of this peculiar type of potassium depletion on renal concentrating ability. The results indicate that in rats, potassium depletion induced by magnesium deficiency, in contrast to potassium deficiency produced by other means, does not impair the ability of the kidneys to concentrate urine. Strikingly different effects upon weight, strength, and behavior were also noted.

\section{MATERIAL AND METHODS}

Studies were carried out on 161 white, male, SpragueDawley rats weighing 140 to $200 \mathrm{~g}$ at the start of the experiment. During the whole experimental period, the rats were fed with one of the four following synthetic diets: normal, magnesium-deficient (referred to in the text as "no-Mg"), potassium deficient ("no-K"), and a diet deficient in both potassium and magnesium ("no-K, no-Mg"). The composition of all these diets is given in Table I. Distilled water and food were given ad libitum to all rats except to those of Group II A (see below), pair-fed controls whose food, but not water, was restricted.

* Supported in part by grants H-834 and 2A-5015 from the U. S. Public Health Service and by the Lawrence Gelb Foundation.

† Trainee of the National Institute of Arthritis and Metabolic Diseases under grant 2A-5015, U. S. Public Health Service, Bethesda, Md. Present address: Second Department of Internal Medicine, Medical Academy, Gdansk, Poland.
Four different sets of experiments were carried out. In Group I (49 rats), I A (normal) comprised 11 rats fed the normal diet for 14 days ( 5 rats) and 56 days ( 6 rats), and then sacrificed; in I B (no-Mg), 30 rats were fed the no- $\mathrm{Mg}$ diet for 14 to 75 days and then sacrificed; and in $\mathrm{I} C$ (no-K), 8 rats were fed the no-K diet for 14 days and then sacrificed. In Group II (16 rats), the 7 rats of II A (normal) were pair-fed for 28 days with the rats of II $B$ and then sacrificed; in II B (no- Mg), 9 rats were fed the no- $\mathrm{Mg}$ diet for 28 days and then sacrificed. In Group III (64 rats), the 12 rats of III A (normal) were fed the normal diet for 16 days ( 6 rats) and 33 days ( 6 rats), and then sacrificed; in III B (no-Mg), 16 rats were fed the no-Mg diet for 32 days and then sacrificed. In III C (no-K) 18 rats were divided into two subgroups. Six rats were fed the no-K diet for 15 days and then sacrificed; 12 rats were first kept on the no- $\mathrm{K}$ diet for 14 days, then on the no- $\mathrm{Mg}$ diet for another 14 days and then sacrificed. In III D (no-K, no-Mg), 18 rats were also divided into two subgroups. Eight rats were fed the no-K, no-Mg diet for 15 days and then sacrificed; 10 were first kept for 14 days on the no- $\mathrm{K}$, no- $\mathrm{Mg}$ diet and then for another 14 days on the no- $\mathrm{Mg}$ diet. Four died during this time; the remaining 6 were sacrificed at the end of the period. In Group IV (32 rats), the 12 rats of IV A (normal) were kept for 14 days ( 6 rats) and 21 days ( 6 rats) on the normal diet, and then sacrificed; in IV B (no-K), 12 rats were fed the no- $\mathrm{K}$ diet for 14 days ( 6 rats) and 21 days (6 rats), and then sacrificed; in IV C (no-K), 8 rats were first kept for 14 days on the no- $K$ diet, then for another 7 days on the no- $\mathrm{K}$, no- $\mathrm{Mg}$ diet, and then sacrificed.

In all rats, renal concentrating ability was tested before sacrifice. In Groups I, II, and IV, the concentrating test was also done before the animals were started on special diets. In some instances (indicated under Results), the test was also performed at different stages of the experimental period.

Renal concentrating ability was tested as follows. Eight hours after food and water were taken away, $50 \mathrm{mU}$ of vasopressin in oil ${ }^{1}$ was injected subcutaneously in each rat and micturition was induced. Rats were placed in individual metabolic cages over funnels which contained screens to deflect feces and were filled with mineral oil to prevent evaporation of urine. Urine was then collected for the next 16 hours. Micturition was induced again

1 Pitressin Tannate in Oil, Parke, Davis \& Company, Detroit, Mich. 
TABLE I

Composition of diets

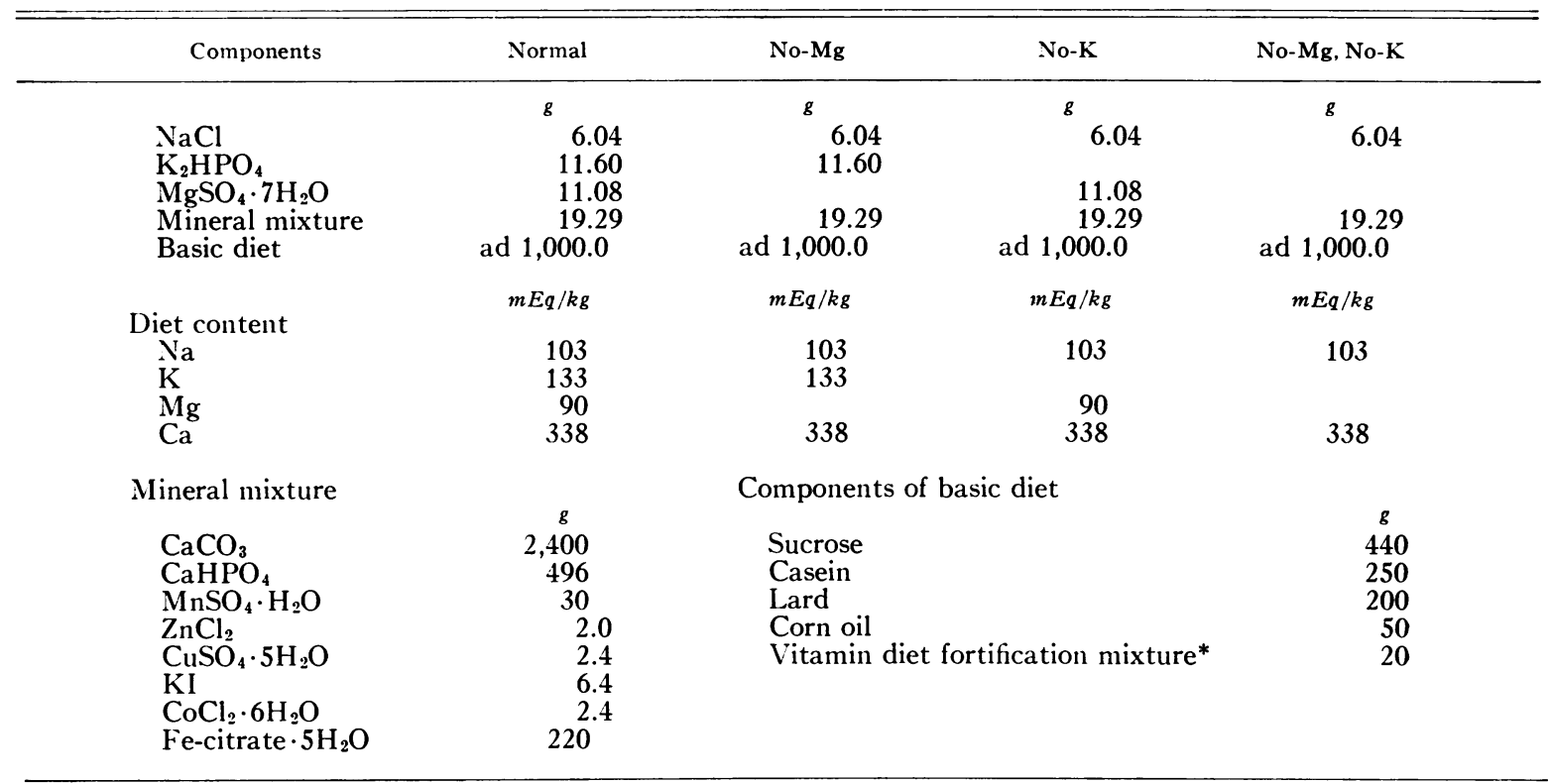

* Nutritional Biochemicals Corporation, Cleveland, Ohio.

and the urine added to that previously collected in the funnel.

Animals were sacrificed soon after the concentrating test was finished. They were anesthetized with sodium pentobarbital and the abdominal cavity was opened. Blood was taken from the abdominal aorta into a heparinized syringe; in Group II, care was taken to obtain the blood anaerobically. After blood was drawn, thigh muscles from both legs were excised. In Group III, before muscles were removed, kidneys were taken out and separate pieces of cortex and of papilla with a small amount of adjacent inner medulla were dissected.

Analysis of water, sodium, and potassium content in kidneys and muscles, and osmolality, sodium, potassium, calcium, $\mathrm{CO}_{2}$, ammonia, and urea of plasma and urine were done as described previously $(6,7)$. Magnesium in plasma was determined by the method of Orange and Rhein (8).

Statistical analysis was done by $t$ test; two compared values were considered significantly different if $p<0.05$.

\section{RESULTS}

1. Gencral obscrvations. Rats fed a no-Mg diet displayed characteristic clinical features described previously by other authors $(4,9)$. Hyperemia of the ears developed in almost all, usually within the first week on a no-Mg diet, and was never noted in control animals. Red ears persisted for a few days and then disappeared, to return later only in a few rats. In most, necrotic lesions of the ear lobes and of the skin were observed after more than 2 weeks of a no- $\mathrm{Mg}$ diet. The rats were strong, very excitable, and aggressive, and occasionally had seizures. Of 55 rats fed the no- $\mathrm{Mg}$ diet, 8 died, 1 each on day $9,14,16,19,20,24,30$, and 40. No control rats died during the experiments. No signs of either polydipsia or polyuria were noted in Mg-deficient rats. Their susceptibility to pentobarbital anesthesia was not increased, and a dose at least equal to that required by normal rats was needed to anesthetize them.

Rats fed a no-K diet, on the other hand, were weak, polydipsic, and polyuric, and presented all other clinical features described previously (6, $10,11)$. The anesthetic dose of pentobarbital was considerably reduced.

Rats fed a no-K, no-Mg diet were much stronger and more excitable than rats depleted solely of potassium, but less so than Mg-deficient animals. Hyperemia of the ears was also noted, but appeared later than in rats fed the no- $\mathbf{M g}$ diet, i.e., usually in the second week. During 2 weeks of observation, no skin lesions were observed and none of the 18 rats fed this diet died. ${ }^{2}$

\footnotetext{
2 In other studies, 4 of 6 rats maintained up to 40 days on the no- $\mathrm{K}$, no- $\mathrm{Mg}$ diet died, on day $28,30,33$, and 35 .
} 


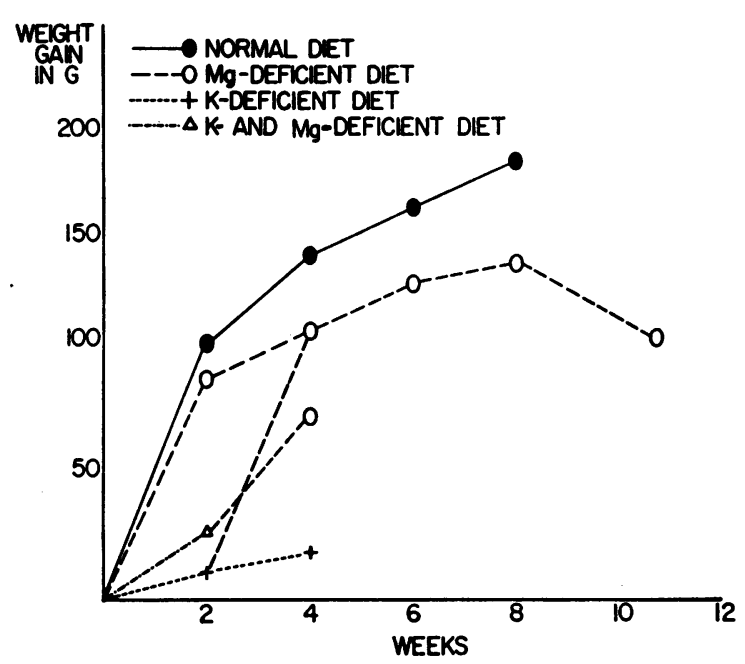

Fig. 1. Weight gain in Rats (Groups I and III) FED AD LIBITUM WITH VARIOUS DIETS. Weight gain was restricted in rats fed a no- $\mathrm{Mg}$ or no- $\mathrm{K}$ diet. The difference between normal and $\mathrm{Mg}$-deficient rats at 4, 6, and 8 weeks is significant $(p<0.01)$.

2. Weight gain (Figures 1 and 2). Rats fed a no-Mg diet gained weight during the first 8 weeks of feeding, but lost when kept longer on the diet. Mg-deficient rats gained weight more slowly than animals fed a normal diet ad libitum. The difference was not abolished by pair feeding. Rats fed the no- $\mathrm{K}$, no- $\mathrm{Mg}$ diet gained more weight than rats fed a diet deficient only in potassium. In both of these groups, the increase of weight was

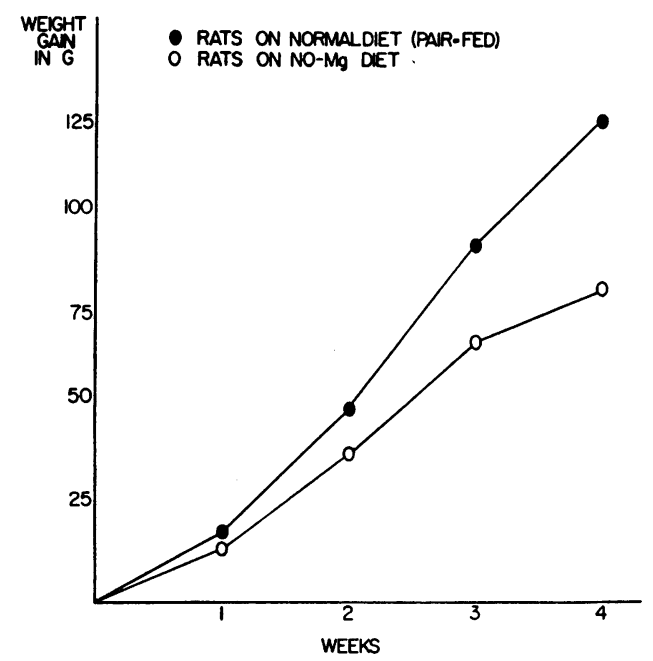

Fig. 2. Weight Gain IN Mg-Deficient Rats AND THEIR PAIR-FED CONTROLS (Group II). Pair-feeding did not abolish the difference in weight gain between normal animals and those on a $\mathrm{Mg}$-deficient diet. The differences at 3 and 4 weeks are significant $(p<0.01)$. much smaller than in rats fed the no- $\mathrm{Mg}$ diet. The difference in body weight, however, rapidly dwindled when the $\mathrm{K}$-deficient diets were replaced by a no-Mg diet containing potassium.

3. The effect of a Mg-deficient diet on the composition of plasma, urine, and muscle (Tables II$\mathrm{IV}$ and Figure 3). After 2 weeks on a no-Mg diet, plasma magnesium was depressed and remained low throughout longer periods of mag-

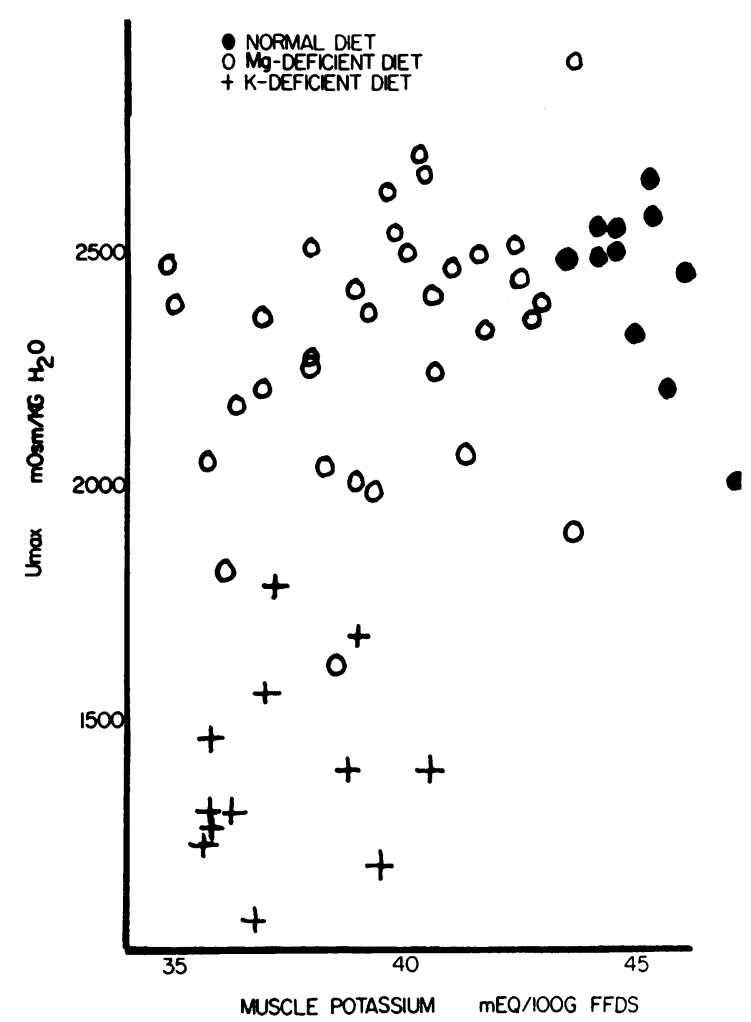

Fig. 3. Relationship Between muscle potassium AND MAXIMAL URINARY OSMOLALITY IN NORMAL RATS AND MG- OR K-DEFICIENT RATS. Mg-deficient rats concentrated their urine normally, although muscle potassium fell to levels comparable to those found in hyposthenuric rats on a K-free diet. FFDS = fat-free dry solids.

nesium deprivation. Plasma sodium was slightly elevated at first, but in later stages of magnesium deficiency returned to normal. Plasma potassium was unchanged in rats fed up to 75 days on a no- $\mathrm{Mg}$ diet. The concentration of calcium in plasma was not significantly altered, although some of the Mg-deficient rats had slight hypercalcemia. This was observed more regularly in a later set of experiments (Table IV). Plasma urea was slightly but significantly increased only 


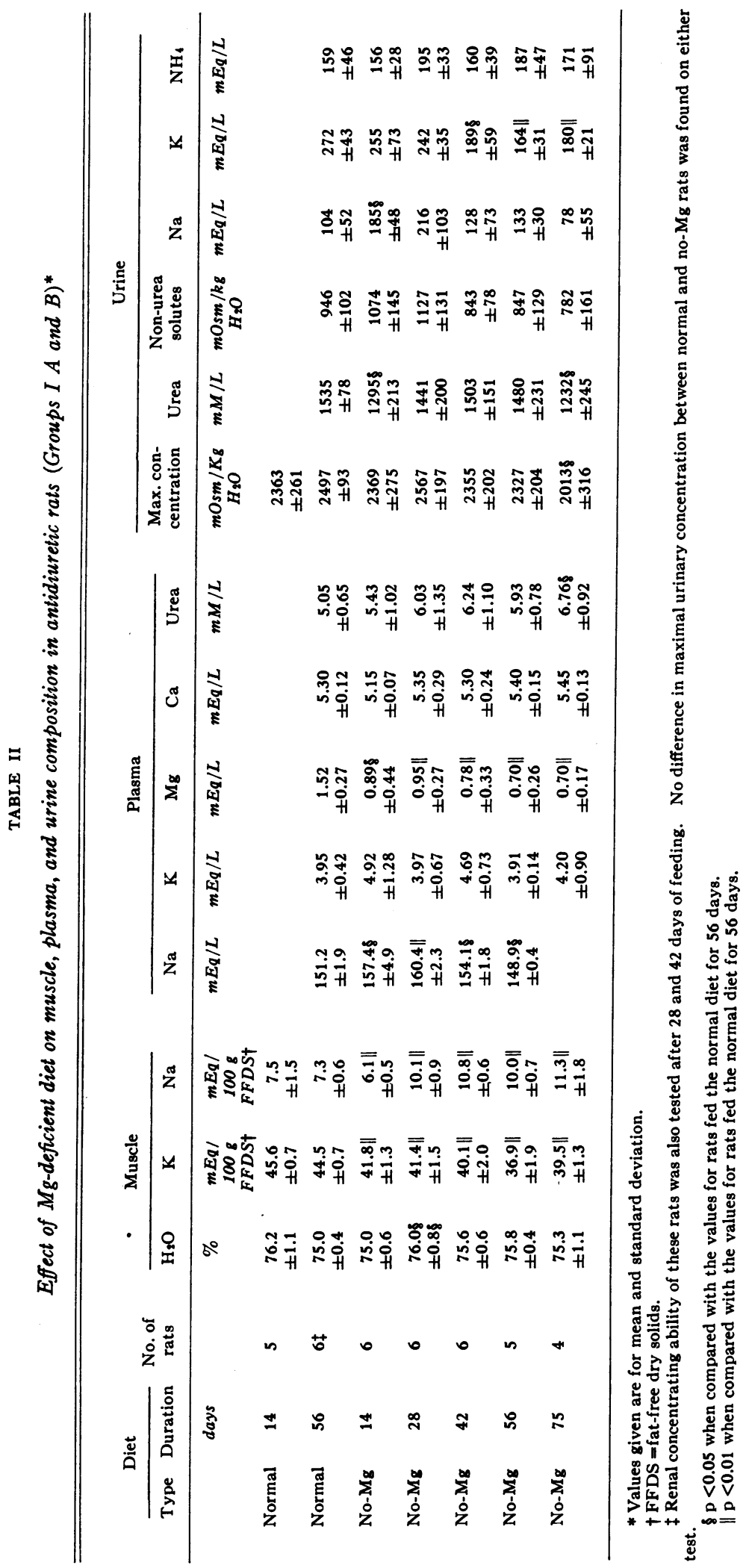


TABLE III

Effect of Mg-deficient diet on plasma $\mathrm{CO}_{2}$ and pH of urine* in rats (Groups II A and B)

\begin{tabular}{|c|c|c|c|c|c|c|c|c|}
\hline \multicolumn{2}{|c|}{ Diet } & \multirow[b]{2}{*}{$\begin{array}{c}\text { No. of } \\
\text { rats }\end{array}$} & \multicolumn{2}{|c|}{ Muscle } & \multicolumn{2}{|c|}{ Plasma } & \multicolumn{2}{|c|}{ Urine } \\
\hline Type & $\underset{\text { Dura- }}{\text { Dion }}$ & & $\mathrm{K}$ & $\mathrm{Na}$ & $\mathrm{Mg}$ & $\mathrm{CO}_{2}$ & $\begin{array}{l}\text { Max. con- } \\
\text { centration }\end{array}$ & $\mathrm{pH}$ \\
\hline & deys & & $\underset{F F D S \dagger}{m E q / 100 \mathrm{~g}}$ & $\underset{F F D S \dagger}{m E q / 100 \mathrm{~g}}$ & $m E q / L$ & $m M / L$ & $\mathrm{mOsm} / \mathrm{kg} \mathrm{H} \mathrm{H}_{2} \mathrm{O}$ & \\
\hline $\begin{array}{l}\text { Normal } \\
\text { No-Mg } \\
\text { p }\end{array}$ & $\begin{array}{l}28 \\
28\end{array}$ & $\begin{array}{l}7 \\
9\end{array}$ & $\begin{array}{l}44.2 \pm 1.7 \\
38.5 \pm 1.5 \\
<0.001\end{array}$ & $\begin{array}{c}8.8 \pm 0.8 \\
11.8 \pm 1.1 \\
<0.001\end{array}$ & $\begin{array}{c}1.66 \pm 0.12 \\
0.69 \pm 0.16 \\
<0.001\end{array}$ & $\begin{array}{l}26.9 \pm 1.3 \\
25.0 \pm 1.1 \\
\quad<0.01\end{array}$ & $\begin{array}{c}2410 \pm 131 \\
2388 \pm 212 \\
\text { NS }\end{array}$ & $\begin{array}{c}5.63 \pm 0.18 \\
5.86 \pm 0.23 \\
<0.05\end{array}$ \\
\hline
\end{tabular}

* Values given are for mean and standard deviation.

† FFDS = fat-free dry solids.

after 75 days of magnesium deficiency. Plasma $\mathrm{CO}_{2}$ was slightly lower and urinary $\mathrm{pH}$ slightly higher than normal in $\mathrm{Mg}$-deficient rats.

Muscle potassium was decreased after 2 weeks of magnesium deficiency, and remained low thereafter. Muscle sodium increased. Despite clearcut potassium depletion as evidenced by analysis of muscle, maximal urinary concentration was undiminished. ${ }^{3}$

4. The effect of magnesium deficiency on the composition of kidney tissue (Table IV). The potassium content of renal medulla was significantly lower than normal in rats fed no- $\mathrm{Mg}$, and no- $\mathrm{K}$, no- $\mathrm{Mg}$ diets, as well as in rats depleted only of potassium. Potassium of renal cortex was not

3 The drop of maximal urinary concentration in rats fed a no-Mg diet for 75 days was mainly due to a low urine osmolality of 1 of the 4 rats. The individual values of maximal urinary concentration in this group were: 1612, 1992, 2080, $2380 \mathrm{mOsm}$ per $\mathrm{kg} \mathrm{H}_{2} \mathrm{O}$. perceptibly influenced by dietary deficiency of magnesium or potassium. ${ }^{4}$ The potassium content of the medulla in $\mathrm{Mg}$-deficient rats approximated that of rats deficient in potassium alone or in both potassium and magnesium. This fall in tissue potassium could not be accounted for by a decrease in urinary concentration of potassium. Despite potassium depletion of medullary tissue, $M g$-deficient rats concentrated the urine normally.

The sodium content of medullary tissue was significantly higher in rats that concentrated urine normally (normal and no- $\mathrm{Mg}$ groups) than in rats with hyposthenuria (no- $\mathrm{K}$ and no- $\mathrm{K}$, no- $\mathrm{Mg}$ groups). This confirms previous observations that in K-deficient animals, the content of sodium of the renal papilla is decreased (6).

4 Prolonged feeding (35 days) with $\mathrm{K}$-free diets does result in a decreased potassium content of renal cortex in rats (6).

TABLE IV

Effect of different diets on muscle, plasma, urine, and

\begin{tabular}{|c|c|c|c|c|c|c|c|}
\hline \multicolumn{2}{|l|}{ Diet } & \multirow{2}{*}{$\begin{array}{c}\text { No. of } \\
\text { rats }\end{array}$} & \multicolumn{2}{|c|}{ Muscle } & \multicolumn{3}{|c|}{ Plasma } \\
\hline Type & $\overline{\text { Duration }}$ & & $\mathrm{K}$ & $\mathrm{Na}$ & $\mathrm{K}$ & $\mathbf{M g}$ & $\mathrm{Ca}$ \\
\hline & days & & $\underset{F F D S \dagger}{m E q / 100 \mathrm{~g}}$ & $\underset{F F D S \dagger}{m E q / 100 g}$ & $m E q / L$ & $m E q / L$ & $m E q / L$ \\
\hline Normal & $16,33 \ddagger$ & 12 & $\begin{array}{r}44.1 \\
\pm 0.7\end{array}$ & $\begin{array}{r}7.4 \\
\pm 1.0\end{array}$ & $\begin{array}{r}3.61 \\
\pm 0.46\end{array}$ & $\begin{array}{r}2.02 \\
\pm 0.30\end{array}$ & $\begin{array}{r}5.15 \\
\pm 0.37\end{array}$ \\
\hline No-Mg & 32 & 11 & $\begin{array}{c}38.2 \| \\
\pm 2.3\end{array}$ & $\begin{array}{c}10.2 \| \\
\pm 1.1\end{array}$ & $\begin{array}{r}3.87 \\
\pm 0.62\end{array}$ & $\begin{array}{c}0.91 \| \\
\pm 0.28\end{array}$ & $\begin{array}{r}5.56 \| \\
\pm 0.23\end{array}$ \\
\hline No-K & 15 & 6 & $\begin{array}{c}35.2 \| \\
\pm 3.1\end{array}$ & $\begin{array}{l}13.7 \| \\
\pm 2.8\end{array}$ & $\begin{aligned} & 2.22 \| \\
\pm & 0.27\end{aligned}$ & $\begin{array}{r}2.29 \\
\pm 0.25\end{array}$ & \\
\hline No-K, no-Mg & 15 & 8 & $\begin{array}{l}31.8 \| \\
\pm 2.5\end{array}$ & $\begin{array}{l}19.1 \| \\
\pm 1.1\end{array}$ & $\begin{array}{l}1.91 \| \\
\pm 0.25\end{array}$ & $\begin{array}{c}0.82 \| \\
\pm 0.11\end{array}$ & \\
\hline
\end{tabular}

* Values given are for mean and standard deviation.

$\dagger$ FFDS $=$ fat-free dry solids.

$\ddagger$ No significant differences were found between the results obtained in normal rats sacrificed after 16 and after 33 days; these data have therefore been combined.

$\$ p<0.05$ when compared with normal values.

$\| \mathrm{p}<0.01$ when compared with normal values. 
5. The effect of Mg-deficient diet on rats previously depleted of potassium (Tables V and VI). When rats previously depleted of potassium by a no-K diet were then also depleted of magnesium, renal concentrating ability, initially impaired by potassium deprivation, remained low (Table V). On the other hand, if potassium was restored to the diet at the same time that magnesium was withdrawn, renal concentrating ability generally improved, and in some cases became normal, even though muscle potassium, although increasing, continued to be below normal limits (Table VI).

\section{DISCUSSION}

The depletion of tissue potassium induced in rats by magnesium deficiency differs in several important respects from that induced by potassium deficiency. In contrast to the latter, magnesium deficiency does not lower serum potassium or reduce urinary excretion of potassium. Extracellular alkalosis is absent and urinary excretion of ammonia does not rise. Despite substantial reduction in the potassium content of muscle, weakness is not apparent, and the depleted rats remain relatively strong and vigorous. The present studies indicate that, although the renal medulla participates in the loss of body potassium that accompanies magnesium deficiency, the ability of the kidneys to concentrate both urea and non-urea solutes remains unimpaired.
One possible explanation of this surprising discrepancy might be that magnesium depletion itself reverses the effects on membrane permeability and enzymatic activity produced by losses of intracellular potassium. In the present experiments, however, renal concentrating ability, already low, did not improve when magnesium depletion was superimposed in rats on a no- $\mathrm{K}$ diet. In these animals, magnesium depletion probably induced further cellular losses of potassium, as suggested by analysis of their muscles. Preservation of normal renal concentrating ability might, therefore, be related to the ratio of cellular stores of magnesium to those of potassium. Another possibility is that in magnesium deficiency, potassium is lost from a different site within the cell than in potassium deficiency alone.

Structural changes in the kidneys of Mg-deficient rats might be expected to differ from those observed in potassium depletion alone. In fact, Kashiwa reported that in $\mathrm{Mg}$-deficient rats the tubular changes are similar to those found in $\mathrm{K}$-depleted animals, but probably are confined mostly to the distal convoluted tubules (9). He also observed foci of calcareous deposits in tubules, especially at the corticomedullary junction. Whang, Oliver, McDowell, and Welt, on the other hand, found intraluminal deposits of calcareous material in the ascending limbs of loops of Henle without any primary changes in renal tubular epithelium (12). Histological examination of the

TABLE IV-(Continued)

renal medullary tissue in rats (Groups III A, B, C, and D)*

\begin{tabular}{|c|c|c|c|c|c|c|c|c|}
\hline \multicolumn{3}{|c|}{ Urine } & \multicolumn{3}{|c|}{ Renal medulla } & \multicolumn{3}{|c|}{ Renal cortex } \\
\hline $\begin{array}{l}\text { Max. os- } \\
\text { molality }\end{array}$ & $\mathrm{Na}$ & $\mathrm{K}$ & $\mathrm{H}_{2} \mathrm{O}$ & $\mathrm{Na}$ & $\mathrm{K}$ & $\mathrm{H}_{2} \mathrm{O}$ & $\mathrm{Na}$ & $\mathrm{K}$ \\
\hline$\underset{\mathrm{H}_{2} \mathrm{O}}{\mathrm{mOsm} / \mathrm{kg}}$ & $m E q / L$ & $m E q / L$ & $\%$ & $\underset{d r y \text { solids }}{m E q / 100 \mathrm{~g}}$ & $\underset{d r y \text { solids }}{m E q / 100 \mathrm{~g}}$ & $\%$ & $\underset{d r y / 100 \mathrm{~g}}{m E q}$ & $\begin{array}{c}m E q / 100 \mathrm{~g} \\
d r y \text { solids }\end{array}$ \\
\hline $\begin{array}{r}2349 \\
\pm 244\end{array}$ & $\begin{array}{r}131 \\
\pm 72\end{array}$ & $\begin{array}{r}308 \\
\pm 61\end{array}$ & $\begin{array}{r}82.7 \\
\pm 1.4\end{array}$ & $\begin{array}{r}95.5 \\
\pm 20.2\end{array}$ & $\begin{array}{r}40.1 \\
\pm 15.4\end{array}$ & $\begin{array}{r}73.9 \\
\pm 0.9\end{array}$ & $\begin{array}{r}18.2 \\
\pm 2.7\end{array}$ & $\begin{array}{r}31.0 \\
\pm 5.0\end{array}$ \\
\hline $\begin{array}{r}2328 \\
\pm 198\end{array}$ & $\begin{array}{r}117 \\
\pm 27\end{array}$ & $\begin{array}{r}204 \\
\pm 71\end{array}$ & $\begin{array}{c}80.5 \| \\
\pm 1.8\end{array}$ & $\begin{array}{r}87.0 \\
\pm 13.7\end{array}$ & $\begin{array}{c}26.2 \| \\
\pm 5.1\end{array}$ & $\begin{array}{r}74.5 \\
\pm 0.6\end{array}$ & $\begin{array}{r}17.3 \\
\pm 2.1\end{array}$ & $\begin{array}{r}29.2 \\
\pm 2.2\end{array}$ \\
\hline $\begin{array}{c}1417 \| \\
\pm 196\end{array}$ & $\begin{array}{r}66 \\
\pm 38\end{array}$ & $\begin{array}{r}3.6 \| \\
\pm 1.8\end{array}$ & $\begin{array}{c}78.2 \| \\
\pm 2.1\end{array}$ & $\begin{array}{c}60.1 \| \\
\pm 7.7\end{array}$ & $\begin{array}{l}21.6 \| \\
\pm 7.8\end{array}$ & $\begin{array}{l}75.4 \S \\
\pm 1.5\end{array}$ & $\begin{array}{r}20.8 \\
\pm 3.6\end{array}$ & $\begin{array}{r}30.3 \\
\pm 3.4\end{array}$ \\
\hline $\begin{array}{c}1569 \| \\
\pm 182\end{array}$ & $\begin{array}{r}83 \\
\pm 51\end{array}$ & 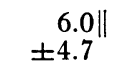 & $\begin{array}{l}78.9 \| \\
\pm 1.1\end{array}$ & $\begin{array}{c}68.1 \| \\
\pm 13.3\end{array}$ & $\begin{array}{c}24.7 \| \\
\pm 5.7\end{array}$ & $\begin{array}{c}76.4 \| \\
\pm 1.6\end{array}$ & $\begin{array}{l}21.8 \S \\
\pm 3.1\end{array}$ & $\begin{array}{r}31.7 \\
\pm 3.5\end{array}$ \\
\hline
\end{tabular}


TABLE V

Effect of superimposing magnesium deficiency upon potassium depletion in rats*

\begin{tabular}{|c|c|c|c|c|c|}
\hline \multirow[b]{2}{*}{ Group } & \multirow{2}{*}{$\begin{array}{l}\text { No. of } \\
\text { rats }\end{array}$} & \multicolumn{2}{|c|}{ Diet } & \multirow{2}{*}{$\begin{array}{l}\text { Max. urinary } \\
\text { concentration }\end{array}$} & \multirow[b]{2}{*}{ Muscle K } \\
\hline & & Type & Duration & & \\
\hline & & & days & $\underset{\mathrm{H}_{2} \mathrm{O}}{\mathrm{mOsm} / \mathrm{kg}}$ & $\underset{F F D S \dagger}{m E q / 100 \mathrm{~g}}$ \\
\hline \multirow[t]{2}{*}{ IV B } & 6 & No-K & 14 & $\begin{array}{l}1,147 \\
\pm 186\end{array}$ & \\
\hline & & No-K & 7 more & $\begin{array}{r}964 \\
\pm 238\end{array}$ & $\begin{array}{r}30.9 \\
\pm 2.7\end{array}$ \\
\hline \multirow[t]{2}{*}{ IV C } & 8 & No-K & 14 & $\begin{array}{l}1,422 \\
\pm 301\end{array}$ & \\
\hline & & No-K, no-Mg & 7 more & $\begin{array}{l}1,092 \\
\pm 303\end{array}$ & $\begin{array}{r}28.0 \\
\pm 3.1\end{array}$ \\
\hline
\end{tabular}

* Values given are for mean and standard deviation.

$\dagger$ FFDS = fat-free dry solids.

kidneys of our Mg-depleted rats showed scattered calcareous deposits at the corticomedullary junction.

In contrast to the present results, hypercalcemia associated with nephrocalcinosis (4), azo- temia (5), and impaired renal concentrating ability (13) have been reported by others in $\mathrm{Mg}$-deficient rats. Perhaps one explanation of these differences lies in the composition of the Mg-deficient diet. Tufts and Greenberg pointed out 25 years

TABLE VI

Effect of Mg-deficient diet on renal concentrating ability in rats previously depleted of potassium (Groups III A, C, and D)

\begin{tabular}{|c|c|c|c|}
\hline \multirow[b]{2}{*}{ Rat no. } & \multirow{2}{*}{$\begin{array}{l}\text { After } 14 \text { days } \\
\text { on no-K diet, } \\
\mathrm{U}_{\max } *\end{array}$} & \multicolumn{2}{|c|}{ After another 14 days on no- $\mathrm{Mg}$ diet } \\
\hline & & $\mathrm{U}_{\max }$ & Muscle K \\
\hline \multicolumn{2}{|r|}{$\mathrm{mOsm} / \mathrm{kg} \mathrm{H} \mathrm{H}_{2} \mathrm{O}$} & $\mathrm{mOsm} / \mathrm{kg} \mathrm{H} \mathrm{H}_{2} \mathrm{O}$ & $\underset{F F D S \dagger}{m E q / 100 \mathrm{~g}}$ \\
\hline $\begin{array}{l}44 \\
45 \\
46 \\
47 \\
48 \\
49 \\
51 \\
52 \\
53 \\
55 \\
57 \\
58\end{array}$ & $\begin{array}{l}1,836 \\
1,352 \\
1,028 \\
1,304 \\
1,320 \\
1,676 \\
1,696 \\
1,884 \\
1,652 \\
1,080 \\
1,568 \\
1,448\end{array}$ & $\begin{array}{l}2,408 \\
2,504 \\
2,580 \\
2,416 \\
1,228 \\
1,024 \\
2,136 \\
2,128 \\
1,068 \\
2,472 \\
2,460 \\
2,232\end{array}$ & $\begin{array}{l}44.4 \\
43.4 \\
42.4 \\
44.7 \\
39.4 \\
41.6 \\
42.4 \\
42.9 \\
40.3 \\
42.6 \\
41.4 \\
40.3\end{array}$ \\
\hline \multicolumn{2}{|r|}{$\begin{array}{l}\text { After } 14 \text { days } \\
\text { on no-K, } \\
\text { no-Mg diet }\end{array}$} & & \\
\hline $\begin{array}{l}67 \\
69 \\
70 \\
72 \\
73 \\
81\end{array}$ & $\begin{array}{l}1,544 \\
1,432 \\
1,148 \\
1,488 \\
1,120 \\
1,672\end{array}$ & $\begin{array}{l}1,480 \\
1,812 \\
1,852 \\
2,788 \\
2,004 \\
2,600\end{array}$ & $\begin{array}{l}41.1 \\
40.0 \\
38.7 \\
42.4 \\
39.4 \\
38.4\end{array}$ \\
\hline \multirow{2}{*}{\multicolumn{2}{|c|}{$\begin{array}{l}6 \text { rats after } 16 \text { days on normal diet } \\
6 \text { rats after } 33 \text { days on normal diet } \\
6 \text { rats after } 15 \text { days on no-K diet } \\
8 \text { rats after } 15 \text { days on no-K, no-Mg diet }\end{array}$}} & $\begin{array}{c}\text { Muscle Kf } \\
m E q / 100 \text { g FFDS* }\end{array}$ & 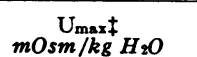 \\
\hline & & $\begin{array}{l}44.5 \pm 0.7 \\
43.8 \pm 0.5 \\
35.2 \pm 3.1 \\
31.8 \pm 2.5\end{array}$ & $\begin{array}{l}2473 \pm 201 \\
2245 \pm 246 \\
1417 \pm 196 \\
1569 \pm 182\end{array}$ \\
\hline
\end{tabular}

* $U_{\max }=$ maximal urinary concentration.

$\dagger$ FFDS = fat-free dry solids.

¥ Values given are for mean and standard deviation. 
ago that an increase in the intake of calcium had an injurious effect on Mg-deficient rats (14). The content of calcium per calorie seems to have been very much lower in our experiments than in those of Smith, Baxter, Lindner, and Ginn, who found impaired concentrating ability in $\mathrm{Mg}$-deficient rats (13). In addition, the ratio of sodium to potassium in the diet was considerably lower in the present experiments than in those reported by Smith and co-workers, in which even control rats had a surprisingly low concentration of potassium in muscle (13). It is apparent that in studies of the physiological role of excesses or deficits of inorganic substances, close attention must be paid to interrelationships between ions that may condition the development of impaired function or tissue injury.

The present experiments indicate that in certain circumstances, magnesium deprivation may induce moderate depletion of potassium without impairing the ability of the kidneys to concentrate urine. Normal urinary specific gravities reported in three K-depleted patients with primary aldosteronism (15-17) may conceivably have been associated with concomitant depletion of magnesium, since it has been shown that the administration of aldosterone markedly increases excretion of magnesium into the urine (18).

\section{SUMMARY}

Rats maintained on a diet deficient in magnesium developed potassium depletion that was reflected in a decreased potassium content of muscle and of renal medullary tissue. Despite this, and in contrast to potassium depletion induced by a diet low in potassium, magnesium deficiency did not impair the ability of the kidneys to concentrate urine.

\section{ACKNOWLEDGMENT}

The authors gratefully acknowledge the technical assistance of Mrs. Nadia Myketey, Mrs. Eva Taborsky, and Mrs. Margaret Davis.

\section{REFERENCES}

1. Welt, L. G., Hollander, W., Jr., and Blythe, W. B. The consequences of potassium depletion. J. chron. Dis. 1960, 11, 213.

2. Conn, J. W., and Johnson, R .D. Kaliopenic nephropathy. Amer. J. clin. Nutr. 1956, 4, 523.
3. Cotlove, E., Holliday, M. A., Schwartz, R., and Wallace, W. M. Effects of electrolyte depletion and acid-base disturbance on muscle cations. Amer. J. Physiol. 1951, 167, 665.

4. MacIntyre, I., and Davidsson, D. The production of secondary potassium depletion, sodium retention, nephrocalcinosis and hypercalcaemia by magnesium deficiency. Biochem. J. 1958, 70, 456.

5. Whang, R., and Welt, L. G. Observations in experimental magnesium depletion. Clin. Res. 1962, 10, 68.

6. Manitius, A., Levitin, H., Beck, D., and Epstein, F. H. On the mechanism of impairment of renal concentrating ability in potassium deficiency. $\mathrm{J}$. clin. Invest. 1960, 39, 684.

7. Manitius, A., Levitin, H., Beck, D., and Epstein, F. $\mathrm{H}$. On the mechanism of impairment of renal concentrating ability in hypercalcemia. $J$. clin. Invest. 1960, 39, 693.

8. Orange, M., and Rhein, H. C. Microestimation of magnesium in body fluids. J. biol. Chem. 1951, 189, 379.

9. Kashiwa, H. K. Magnesium deficiency in intact, in adrenalectomized and in hypophysectomized rats. Endocrinology 1961, 68, 80.

10. Hollander, W., Jr., Winters, R. W., Williams, T. F., Bradley, J., Oliver, J., and Welt, L. G. Defect in the renal tubular reabsorption of water associated with potassium depletion in rats. Amer. J. Physiol. 1957, 189, 557.

11. Muehrcke, R. C. Prolonged potassium deficiency and chronic pyelonephritis in man and animals in Biology of Pyelonephritis. Boston, Little, Brown, 1960, p. 581.

12. Whang, R., Oliver, J., McDowell, M., and Welt, L. G. The renal lesions of magnesium depletion. Clin. Res. 1962, 10, 257.

13. Smith, W. O., Baxter, D. J., Lindner, A. and Ginn, H. E. Effect of magnesium depletion on renal function in the rat. J. Lab. clin. Med. 1962, 59, 211.

14. Tufts, E. V., and Greenberg, D. M. Biochemistry of magnesium deficiency. II. Minimum magnesium requirements for growth, gestation and lactation and effect of dietary calcium level thereon. J. biol. Chem. 1937, 122, 715.

15. Crane, M. G., Vogel, P. J., and Richland, K. J. Observations on a presumptive case of primary aldosteronism. J. Lab. clin. Med. 1956, 48, 1.

16. Fine, D., Meiselas, L. E., Colsky, J., and Oxenhorn, S. Primary aldosteronism. Report of a case and discussion of the pathogenesis. New Engl. J. Med. 1957, 256, 147.

17. Örndahl, G., Hökfelt, B., Ljunggren, E. and Hood, B. Two cases of primary aldosteronism. Comments on differential diagnosis and difficulties in screening. Acta med. scand. 1959, 165, 445.

18. Hanna, S., and MacIntyre, J. The influence of aldosterone on magnesium metabolism. Lancet 1960, 2, 348. 